\title{
Biometrical analysis of three species of the genus Lapeirouseia from the Campanian-Maastrichtian of Stranice (North-East Slovenia)
}

\section{Biometrične analize treh vrst rodu Lapeirouseia iz campanijsko-maastrichtijskih plasti pri Stranicah (severovzhodna Slovenija)}

\author{
Mauro CAFFAU \\ Dipartimento di Scienze Geologiche, Ambientali e Marine. Univerista di Trieste. Via E. Weiss 2, Trieste, \\ Italy \\ E-mail: caffau@univ.trieste.it
}

\begin{abstract}
Key words: Rudists, Campanian-Maastrichtian, Biometry, Phylogenesis, Slovenia
\end{abstract} Ključne besede: rudisti, campanij-maastrichtij, biometrija, filogeneza, Slovenija

\begin{abstract}
The rudist rich deposits of the region of Styria in the north-eastern Slovenia are known since the beginning of the $20^{\text {th }}$ century. Three Lapeirouseia species distributed from Campanian to Maastrichtian are found in this outcrop of the Upper Cretaceous. The biometrical analysis of the species Lapeirouseia zitteli Douvillé, Lapeirouseia laskarevi Milovanović and Lapeirouseia plana Milovanović showed that these three species constitute a single phylogenetic line.
\end{abstract}

\section{Kratka vsebina}

Pri Stranicah v severovzhodni Sloveniji je bogato nahajališče rudistov, znano že od začetka 20.stoletja. S tega zgornjekrednega območja izhajajo tudi tri vrste rodu Lapeirouseia iz campanijskih do maastrichtijskih plasti in sicer Lapeirouseia zitteli Douvillé, L. laskarevi Milovanović in L. plana Milovanović. Te tri vste je avtor raziskal z biometričnimi analizami in dokazal, da predstavljajo isti filogenetski niz.

\section{Introduction}

A rich fauna of rudists that consists of hippuritids and radiolitids coming from the locality of Stranice in the north-east of Slovenia (Fig.1) was recently described by Pleničar and Šribar (1992) and Pleni čar (1993 and 1994). On the basis of the assemblage of benthonic foraminifers the authors assigned the limestones and breccia with rudists to a period ranging from Campanian to Maastrichtian. Moreover, the authors analysed the stratigraphic position of the levels of limestones and breccia with rudists belonging to the Cretaceous limestones of Styria that form part of the Gosau beds.

The most common radiolitids found in the rudist deposit of Stranice belong to the genera Lapeirouseia and Praelapeirouseia. In second place, Radiolites, Biradiolites and Sauvagesia are also found. It is worth noting that among Sauvagesia, the species Lapeirouseia zitteli Douvillé, Lapeirouseia laskarevi Milovanović and Lapeirouseia plana Milovanović have an outer shell morphology apparently very similar among 


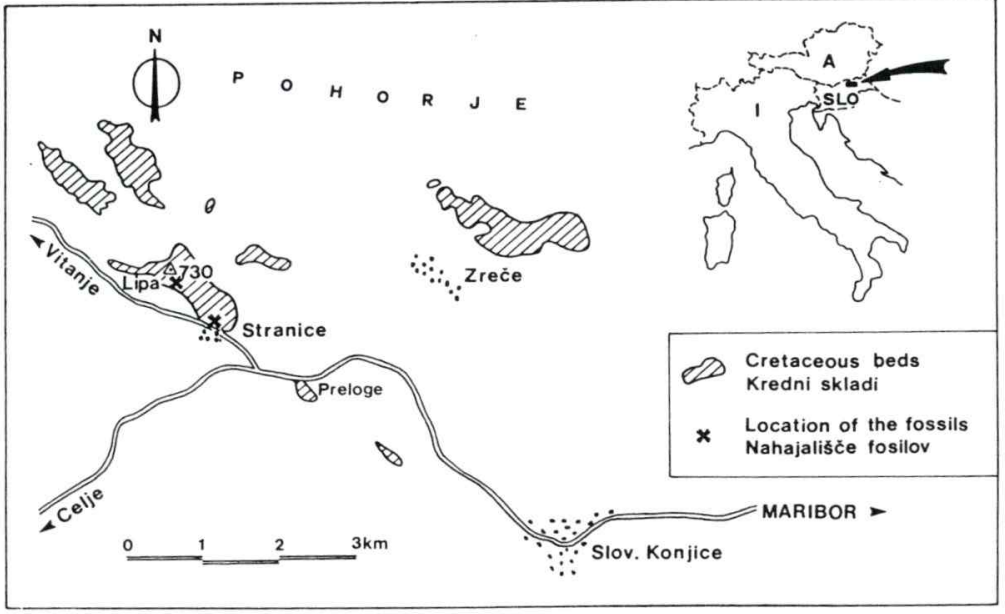

Fig. 1. Location map of the rudist fauna of Stranice them and according to Milovanović (1938 and 1951), L.plana represents the evolution of the more ancient species L. zitteli and L. laskarevi.

The availability of well-preserved specimens of L. zitteli, L. laskarevi and L. plana allowed to study the outer morphological characters of the shells. Subsequently, measures of some biometrical parameters were obtained from the inner morphology.

The aims of the present paper are to describe the different morphostructural characteristics of the shell of the three studied species and to define by means of biometrical analysis whether there is a phylogenetic line that links these species.

\section{Systematic palaeontology}

The main morphostructural characters used for the taxonomy of the genus Lapeirouseia are the cellular structure of the shell and the morphology of the pseudopillars. The outer ornamentations of the shell exhibit a great variability of shape among specimens (intraspecific variations) but the outer ornamentations at the ventral area can be considered as a valid character for the taxonomy of this genus as proposed by Milovanović (1951).

The systematic study of the three mentioned species of Lapeirouseia coming from Stranice was previously done (Ple n i ča r 1993). In that systematic study, the author described the structure of the shell and pseudopillars of the examined valves. Therefore, for the description of the general taxonomic characters of $L$. laskarevi, $L$. plana and L. zitteli see Plen i č a r (1993). However, some remarks on particular morphological characters of each species that are important for the aim of this research are mentioned below.

All specimens found at Stranice that were used for this study are deposited at the University of Ljubljana.

Genus: Lapeirouseia Bayle 1878

Lapeirouseia laskarevi Milovanović 1938 Pl.4, figs.3,5; Pl.6, fig.1.

1938 Lapeirouseia laskarevi n. sp.; Milo$\mathrm{v}$ a n o vi ć, 291-292, fig.5 in text.

1951 Lapeirouseia laskarevi Milovanović; M i 1 ov a n ović , 167-171 and 216-218.

1988 Lapeirouseia laskarevi Milovanović ; P e j ović, Pl.5, fig. 1.

1993 Lapeirouseia laskarevi Milovanović; $\mathrm{Pl}$ en i č a r, 58-59, Pl. 13, figs.1-2.

The structure of the shell and pseudopillars are the most particular characters of this species. The structure of the pseudopillars is more evolved and specialised than that of L. zitteli Milovanović (1951). About L. laskarevi and L. zitteli Milova novi ć (1951) says: "par son aspect extérieur, par le limbe radialment plissé, par la structure de la partie principale de la couche prismatique, L. laskarevi ressemble 
beaucoup a L. zitteli. Toutefois, la partie intérieure de la couche externe et la structure des pseudo-piliers sont beaucoup plus spécialisés, a cause de l'extreme développement de la zone lamelleuse".

The distribution of this species is in the Upper Santonian of eastern Serbia and in the Lower Santonian of the Brač island.

Lapeirouseia plana Milovanović1935 Pl.4, figs.1,2; Pl.5, figs.1,2.

1935 Lapeirouseia plana n.sp.; Milov a nović, 134

1939 Lapeirouseia plana Milovanović; Mil ov a nović 4, Pl. 3, figs. 1-2, textfigs. $8-9$.

1951 Lapeirouseia plana Milovanović; Mi l ov a n ovi ć, 186-190, textfigs. 9-10.

1972 Lapeirouseia plana Milovanović; Sla di ć-Trifunović, 136-137, Pl. 13, fig. 5 .

1993 Lapeirouseia plana Milovanović; Ple $\mathrm{n}$ i č a r, 59-60, Pl. 12, figs. 1-2; Pl. 13. fig. 3.

The structure of the pseudopillars, consisting of small polygonal cells and tiny lamellae, is the most specialised comparing with the same structure of L. laskarevi and L. zitteli. For the description of the specimens of this species from the outcrop of Stranice see Plenič ar (1993).

The stratigraphic distribution is Maastrichtian in Serbia and Bulgaria.
Lapeirouseia zitteli Douvillé 1913

Pl.4, figs.4,6; Pl.6, fig.2.

1913 Lapeirouseia zitteli n.sp.; Douvillé, 92 .

1938 Lapeirouseia zitteli Douvillé; M ilov a n o vi ć , 287-291, figs.3-4 in text.

1951 Lapeirouseia zitteli Douvillé; Milo v a n ov i ć , 159-165 and 211-216, figs.1-3. 1992 Lapeirouseia zitteli Douvillé; Pleni ča r \& Šribar 305, Pl.3, figs.1-2.

1993 Lapeirouseia zitteli Douvillé; Ple $\mathrm{n}$ i č a r, 61, Pl 14, figs. 1-2; Pl. 17, figs. 1-2; Pl. 18, figs. 1-3.

The primitive structure of the pseudopillars that characterises this species is well described by Milovanović (1938). This structure consists of big polygonal cells and lamellae and the pseudopillars occupy smaller areas than those of the species $L$. laskarevi and L. plana.

The distribution of this species is in the Santonian of Untersberg near Salzburg, in the Santonian and Lower Campanian of eastern Serbia and in the Lower Santonian of Monts Apuseni in Romania.

\section{Biometrical parameters}

The parameters are obtained from the transversal sections of right valves in the
Fig. 2. Shell area (Sa) vs inner area (Ia). Regression values and dispersion coefficient are shown.

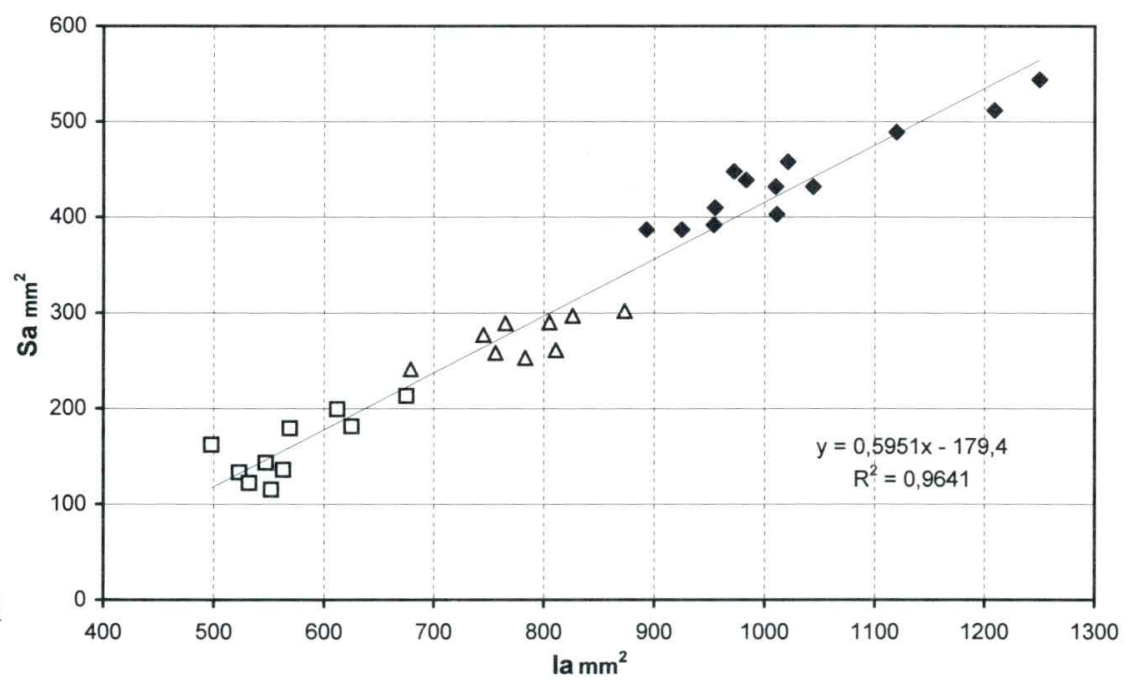




\begin{tabular}{|c|c|c|c|c|c|c|}
\hline & Sa $\mathrm{mm}^{2}$ & la $\mathrm{mm}^{2}$ & (P1-P2)a $\mathrm{mm}^{2}$ & Sa/la & P1^P2 & samples \\
\hline \multirow[t]{13}{*}{ L. plana } & 1250 & 544 & 16 & 2,30 & 62 & 1 \\
\hline & 1044 & 432 & 13 & 2,42 & 55 & 2 \\
\hline & 954 & 392 & 11 & 2,43 & 51 & 3 \\
\hline & 1011 & 403 & 12,5 & 2,51 & 56 & 4 \\
\hline & 983 & 439 & 13,2 & 2,24 & 54 & 5 \\
\hline & 893 & 387 & 11,5 & 2,31 & 50 & 6 \\
\hline & 1021 & 458 & 13,5 & 2,23 & 59 & 7 \\
\hline & 972 & 448 & 12 & 2,17 & 55 & 8 \\
\hline & 1209 & 512 & 14 & 2,36 & 61 & 9 \\
\hline & 955 & 410 & 12,9 & 2,33 & 54 & 10 \\
\hline & 1010 & 432 & 13,2 & 2,34 & 59 & 11 \\
\hline & 1120 & 489 & 15,2 & 2,29 & 57 & 12 \\
\hline & 925 & 387 & 11,5 & 2,39 & 53 & 13 \\
\hline \multirow[t]{9}{*}{ L. laskarevi } & 745 & 277 & 8 & 2,69 & 64 & 24 \\
\hline & 765 & 289 & 9,5 & 2,65 & 52 & 25 \\
\hline & 873 & 302 & 9 & 2,89 & 63 & 26 \\
\hline & 826 & 297 & 10,5 & 2,78 & 51 & 27 \\
\hline & 679 & 241 & 7 & 2,82 & 55 & 28 \\
\hline & 805 & 290 & 8 & 2,78 & 58 & 29 \\
\hline & 783 & 253 & 7,5 & 3,09 & 51 & 30 \\
\hline & 756 & 258 & 7,5 & 2,93 & 56 & 31 \\
\hline & 811 & 261 & 8 & 3,11 & 60 & 32 \\
\hline \multirow[t]{10}{*}{ L. zitteli } & 675 & 213 & 8,5 & 3,17 & 49 & 14 \\
\hline & 563 & 136 & 6,5 & 4,14 & 43 & 15 \\
\hline & 625 & 181 & 7 & 3,45 & 56 & 16 \\
\hline & 523 & 133 & 6 & 3,93 & 44 & 17 \\
\hline & 547 & 143 & 6,5 & 3,83 & 53 & 18 \\
\hline & 612 & 199 & 7,5 & 3,08 & 47 & 19 \\
\hline & 532 & 122 & 5,5 & 4,36 & 56 & 20 \\
\hline & 569 & 179 & 7,5 & 3,18 & 42 & 21 \\
\hline & 498 & 162 & 7 & 3,07 & 54 & 22 \\
\hline & 552 & 115 & 5 & 4,80 & 51 & 23 \\
\hline
\end{tabular}

Table 1. Measures of the parameters Sa, Ia and (P1-P2)a in $\mathrm{mm}^{2}$ and $\mathbf{P} \mathbf{1}^{\wedge} \mathbf{P} 2$ in degrees.

region close to the commisure. These biometrical parameters were previously used in other studies of radiolitids (C e s tari 1992, Caffau and Pleničar 1996, Caffau and Protopsalti 1999) and represent biological characters that are peculiar to the species under study (Pl.1, fig.1a).

- Sa $\left(\mathrm{mm}^{2}\right)$ : shell area or surface of the mantle that is responsible for the incoming 


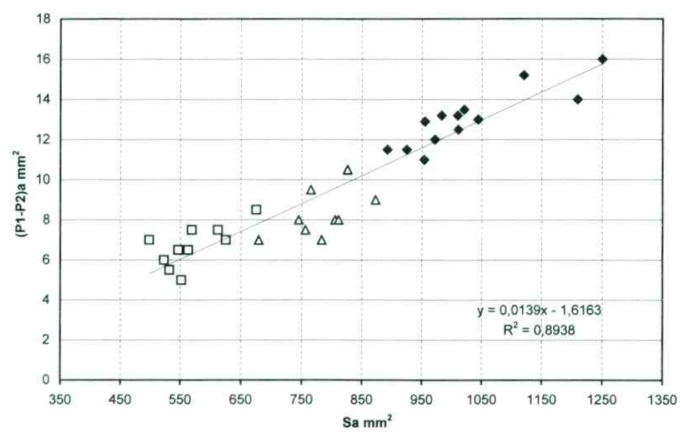

Fig. 3. Pseudopillars area (P1-P2)a vs shell area (Sa). Regression values and dispersion coefficient are shown.

water flux and the entrance of nutrients in the inner cavity

- Ia $\left(\mathrm{mm}^{2}\right)$ : area of the inner cavity that contains the organic tissues.

- (P1-P2) a $\left(\mathrm{mm}^{2}\right)$ : area of the pseudopillars $\mathrm{P} 1$ and $\mathrm{P} 2$

- P1^P2: measure of the angle P1^P2

The values of these parameters obtained from all the analysed transverse sections (Tab.1) are plotted in dispersion diagrams.

The plot Sa versus Ia (Fig.2) show a very good correlation between the parameters Sa and Ia with a coefficient of determination $R^{2}=0.9641$ very close to the unit. There is also a good correlation between the parameters (P1-P2) a and Sa (Fig.3) with $\mathrm{R}^{2}=0.8938$.

The plot Sa/Ia versus P1^P2 (Fig.4) puts in evidence three fields of values. Each one of these fields consists of values belonging to individuals of the same species.

In all the plots, the values form three distinct groups, limited in not overlapping fields that characterise each species.

\section{Discussion}

The presence of the three species with different chronological distribution in the same level of breccia should be seen as a result of the process of reworking.

Due to the great intraspecific variability of the outer morphological characters the systematic attribution of the specimens of L. zitteli, L. laskarevi and L. plana may often be difficult. The analysis of the biometrical data showed the formation of distinct groups of values that characterise each

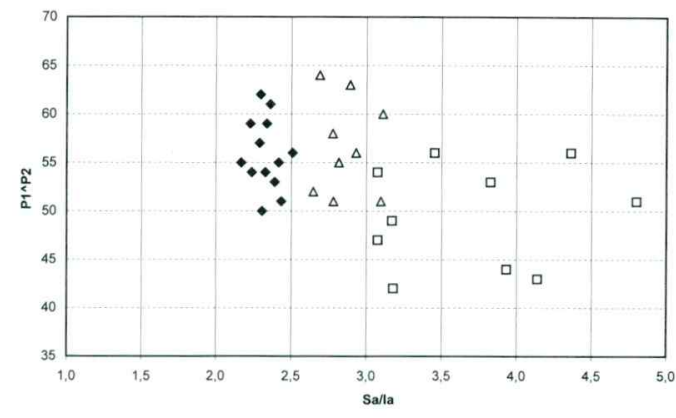

Fig. 4. Ratio $\mathbf{S a / I a ~ v s ~} \mathbf{P 1} \mathbf{1}^{\wedge} \mathbf{P 2}$ in degrees.

species. Moreover, the parameter values increase from the most ancient species to the most recent one. It is noteworthy that this kind of analysis is an important tool to give a reliable systematic attribution to specimens of these species.

Finally, the good correlation between the biometrical parameters Sa and Ia, (P1-P2)a and $\mathbf{P} 1^{\wedge} \mathbf{P} 2$ of $L$. zitteli, L. laskarevi and $L$. plana confirms that they are involved in the same phylogenetic line.

\section{Acknowledgements}

I would like to thank Prof. Mario Pleničar from the Palaeontological Chair of the University of Ljubljana who made possible this research work providing useful advice during the initial phase of the research of specimens at Stranice and the helpful discussion of the final results.

\section{Biometrične analize treh vrst rodu Lapeirouseia iz campanijsko- maastrictijskih plasti pri Stranicah (severovzhodna Slovenija)}

Bogata favna hipuritidov in radiolitidov pri Stranicah v severovzhodni Sloveniji dokazuje campanijsko do maastrichtijsko starost plastem, podobnim gosauskim. Najpogostnejše vrste radiolitidov pripadajo tu rodovoma Lapeirouseia in Praelapeirouseia. Pozornost vzbujajo vrste $L a-$ peirouseia zitteli Douvillé, L. laskarevi Milovanović in L. plana Milovanović, ki so po zunanji plasti spodnjih lupin morfološko med seboj zelo podobne in ki po Milo- 
vanoviću (1938, 1951) predstavljajo razvojni niz od $L$. zitteli in $L$. laskarevi $v$ $L$. plana. Avtor je izvršil primerjavo morfoloških značilnosti zunanjih lupin teh vrst. Morfološke parametre je dobil s prečnih presekov desnih lupin, narejenih najverjetnje blizu njihovih komisur. Ti parametri, ki predstavljajo značilne biološke značilnosti teh vrst na prečnih presekih lupin in so jih uporabljali že prej drugi avtorji pri preučevanju rudistov, so naslednji:

Sa $\left(\mathrm{mm}^{2}\right)=$ površina preseka lupine

Ia $\left(\mathrm{mm}^{2}\right)=$ površina notranje votline, $\mathrm{ki}$ vsebuje organsko tkivo

P1 - P2 $\left(\mathrm{mm}^{2}\right)=$ površina psevdostebričkov $\mathrm{P} 1$ in $\mathrm{P} 2$

Velikost kota $\mathbf{P} \mathbf{1}^{\wedge} \mathbf{P} 2$ med psevdostebričkoma $\mathrm{P} 1$ in $\mathrm{P} 2$

Diagrami, ki kažejo razmerja med $\mathrm{Sa}$ in Ia, $\mathrm{P} 1-\mathrm{P} 2$ in $\mathrm{Sa}$ ter $\mathrm{Sa} / \mathrm{Ia}$ in $\mathrm{P} 1{ }^{\wedge} \mathrm{P} 2$ dokazujejo, da omenjene tri vrste rodu Lapeirouseia pripadajo istemu filogenetskemu nizu. Skupno nastopanje teh treh vrst v breči v istem nahajališču nam tudi kaže na način poteka njihovega transporta.

\section{References}

Caffau, M. \& Pleničar, M. 1996: Biometrical analysis on Biradiolites angulosus d'Orbigny in the stratigraphic sequence of the Bay of Sistiana (Trieste Karst-Italy).- Razprave IV. razreda SAZU, 37 (5), 99-117, Ljubljana.

Caffau, M. \& Protopsalti, I. 1999: A study of the morphological variability of Radio- lites marinii Caffau \& Pleničar (Radiolitidae), Late Cenomanian, Karst of Gorizia, Italy. Annales. Ser. Hist. Nat. 17 (9), 281-295, Koper.

Cestari, R. 1992: Biometrical analysis on gorjanovicias and other radiolitids (Radiolitidae, Hippuritoida). - Geologica Romana, 28, 1-25, Roma.

D o u villé, H. 1913: Sur un Lapeirouseia de Gosau. - C.R. S. g. F. 92-93, Paris.

Milovanović, B. 1935: Rudistna fauna Jugoslavije. - Geol. anali Balk.pol. (Annales Géologique Péninsule Balcanique), 12/2, 273308 , Beograd.

Milovanović, B. 1938: Anatomie comparée et relations phylogénétiques des Lapeirouseiinae. - Bull. Acad. Sci. Serbe math., B, Sciences naturelles, 4, 85-159, Beograd.

Milovanović, B. 1939: Uporedna anatomija i filogenetski odnosi Lapeirouseina. (Comparative anatomy and phylogeny of lapeirouseiina) - Glas Srp. Kralj. Akad. Nauka, 180/89, 169-237, Beograd.

M i l o va n o vi ć, B. 1951: General evolution and taxonomy of Lapeirouseiina. - Geol. Vesnik Savezne uprave za geol. istr., 9, 147-247, Beograd.

Pejović, D. 1988: New Bournonias from the Senonian of Brac. - Bull. Acad. Serbe Sci. Arts, classe sc. Nat. Math., 28, 41-45, Beograd.

Pleničar, M. \& Šribar, L. 1992: Le récif de Rudistes prés de Stranice (N.O. de la Yougoslavie). - Geologica Romana, 28, 305-317, Roma.

Pleničar, M. 1993: Radiolites from the Cretaceous beds of Stranice near Slovenske Konjice (Slovenia). - Razprave IV.razreda SAZU, 34 (3), 45-103 Ljubljana.

Pleničar, M. 1994: Hippuritids from the Upper Cretaceous rudistid reefs near Stranice and Lipa (NE Slovenia). Razprave IV. razreda SAZU, 35 (2), 43-63 Ljubljana.

Sla di ć-Trifunović, M: 1972: Senonski krečnjaci sa orbitoidima i rudistima Kozluka (severoistočna Bosna). - Geol. Anali Balk. Poluostrva, 37 (2), 111-150, Beograd.

\section{Plate 1}

Fig. 1a. Transverse section of a right valve of Lapeirouseia where the measured parameters are indicated.

Figs. 1-8. Lapeirouseia plana. Transverse sections of right valves used for biometrical analysis. Natural size. 


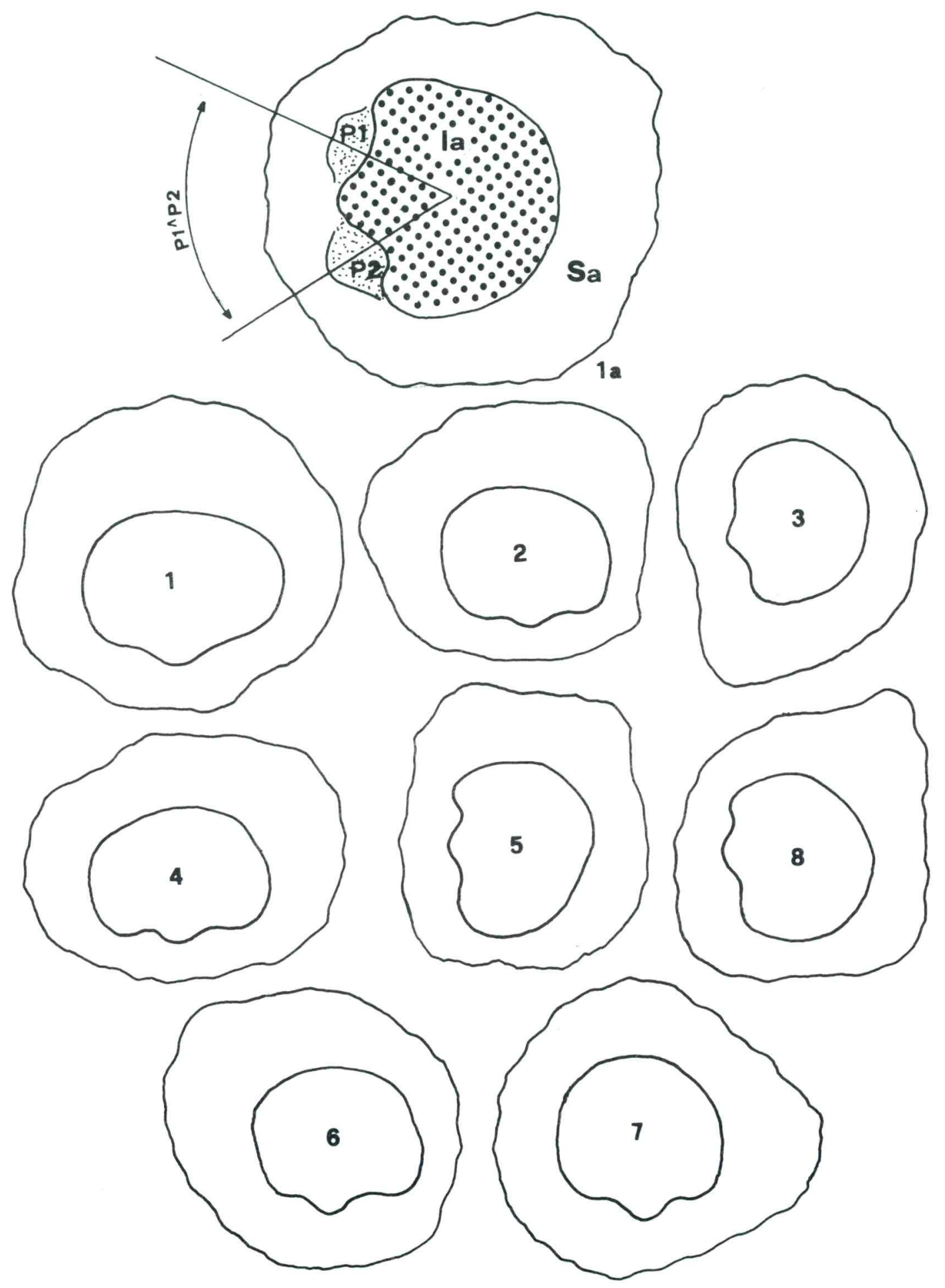



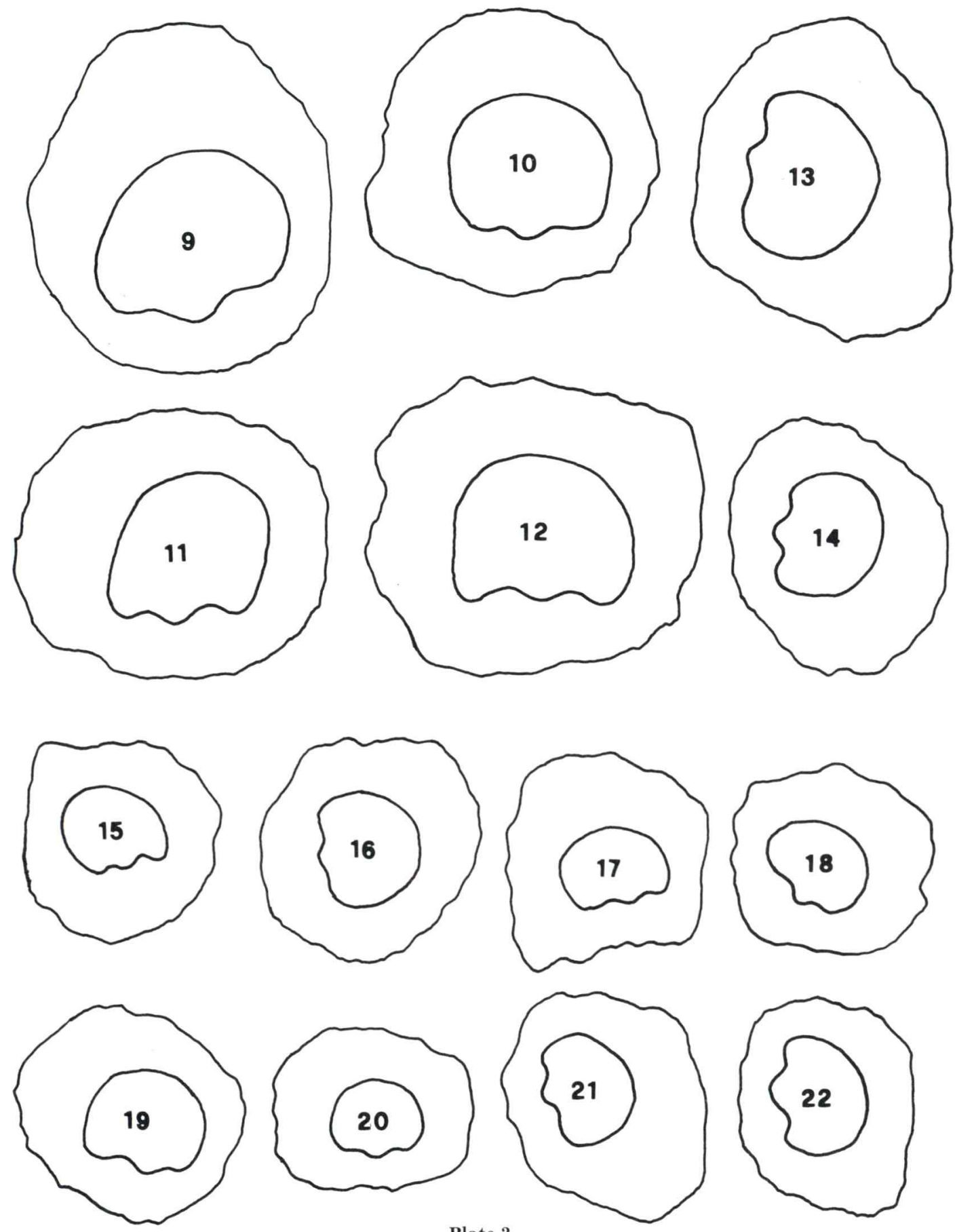

Plate 2

Figs. 9-13. Lapeirouseia plana. Transverse sections of right valves used for biometrical analysis. Natural size.

Figs. 14-22. Lapeirouseia zitteli. Transverse sections of right valves used for biometrical analysis. Natural size. 

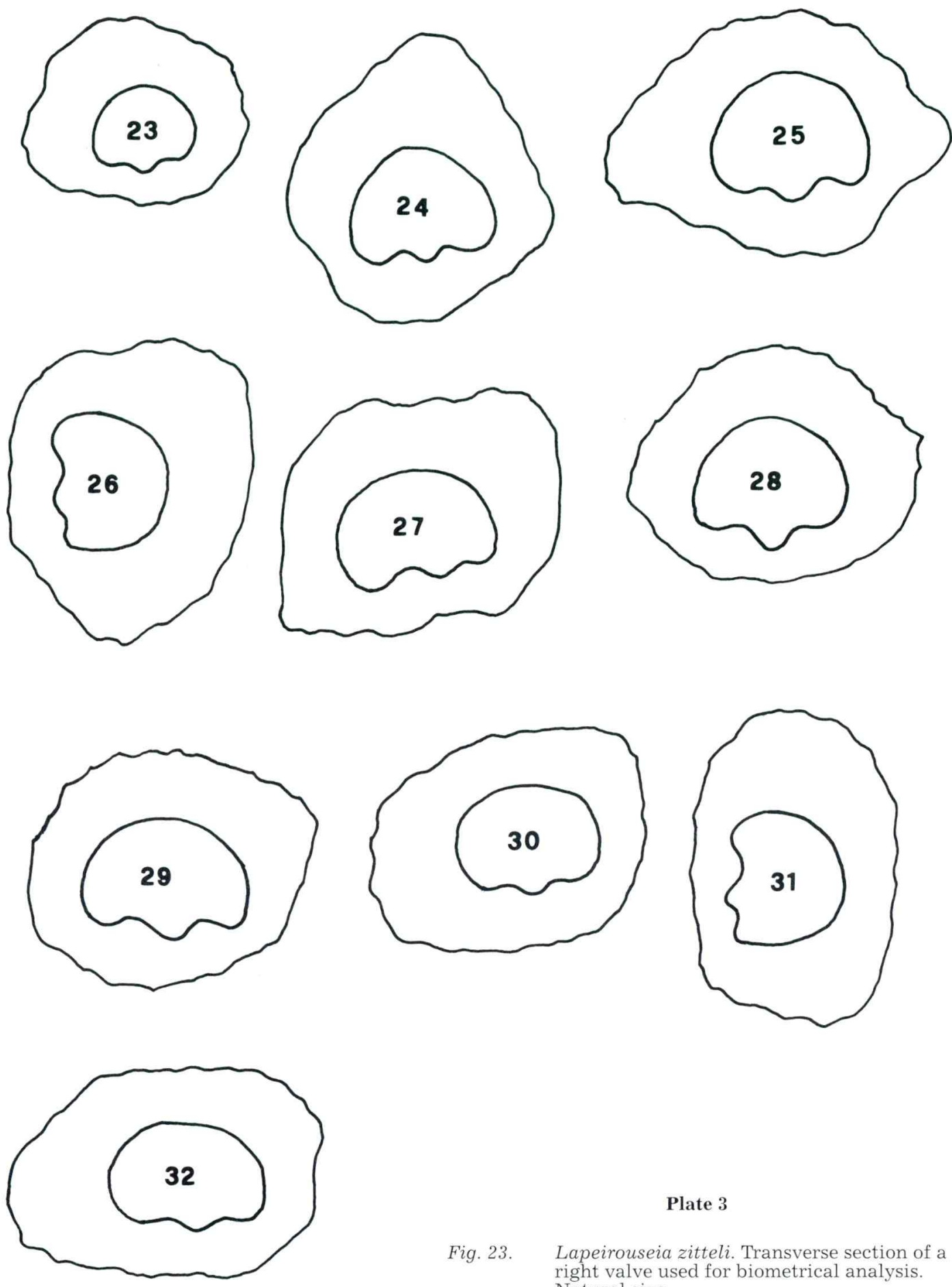

Plate 3

Fig. 23. Lapeirouseia zitteli. Transverse section of a right valve used for biometrical analysis. Natural size.

Figs. 24-32. Lapeirouseia laskarevi. Transverse sections of right valves used for biometrical analysis. Natural size. 


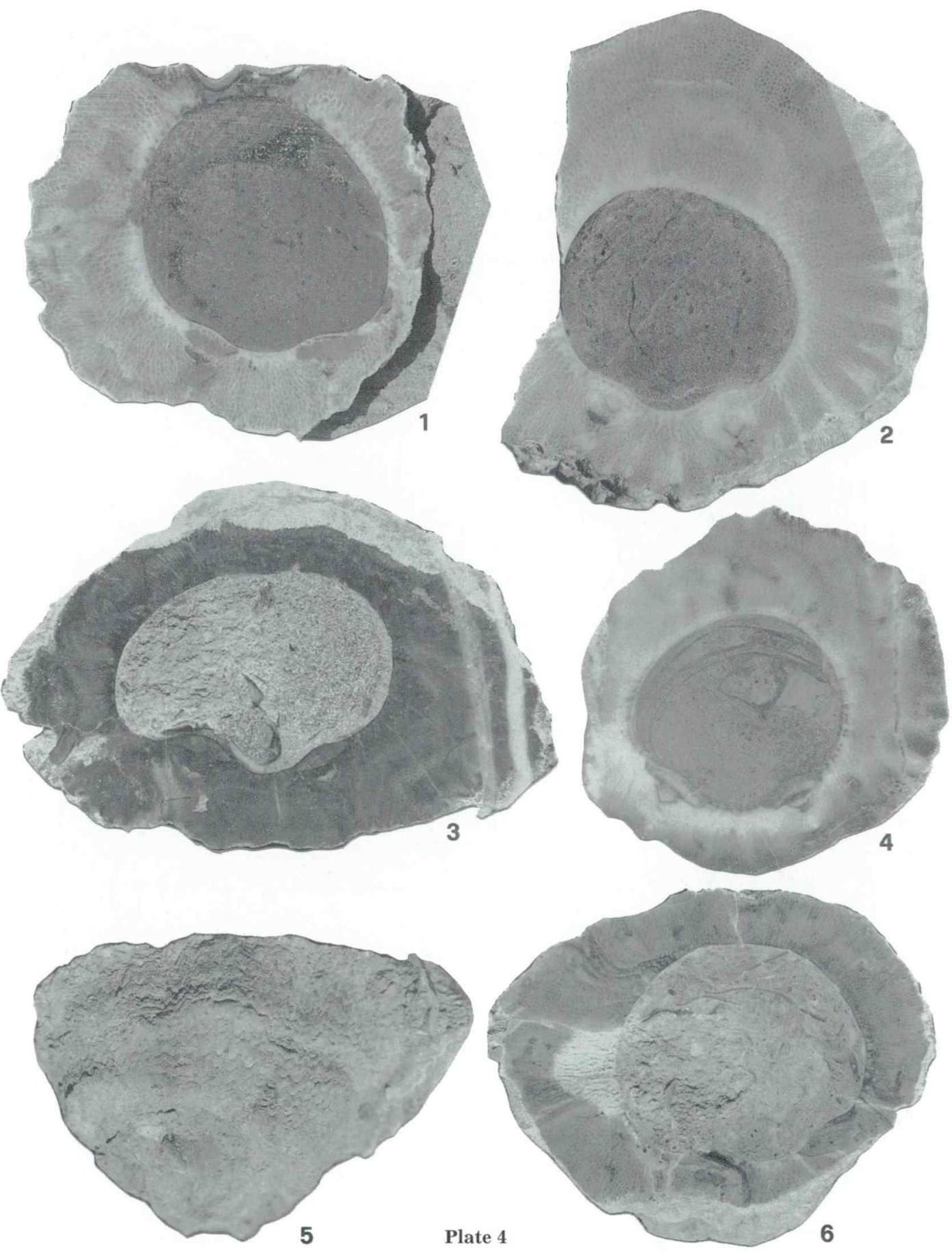

Figs. 1 and 2. Lapeirouseia plana. Polished sections of right valves. $\times 2$.

Figs. 3 and 5. Lapeirouseia laskarevi. Polished section of the right valve $(\times 2)$ and ventral view $(\times 1.8)$ of the same individual.

Figs. 4 and 6. Lapeirouseia zitteli. Polished sections of right valves. $\times 2$. 


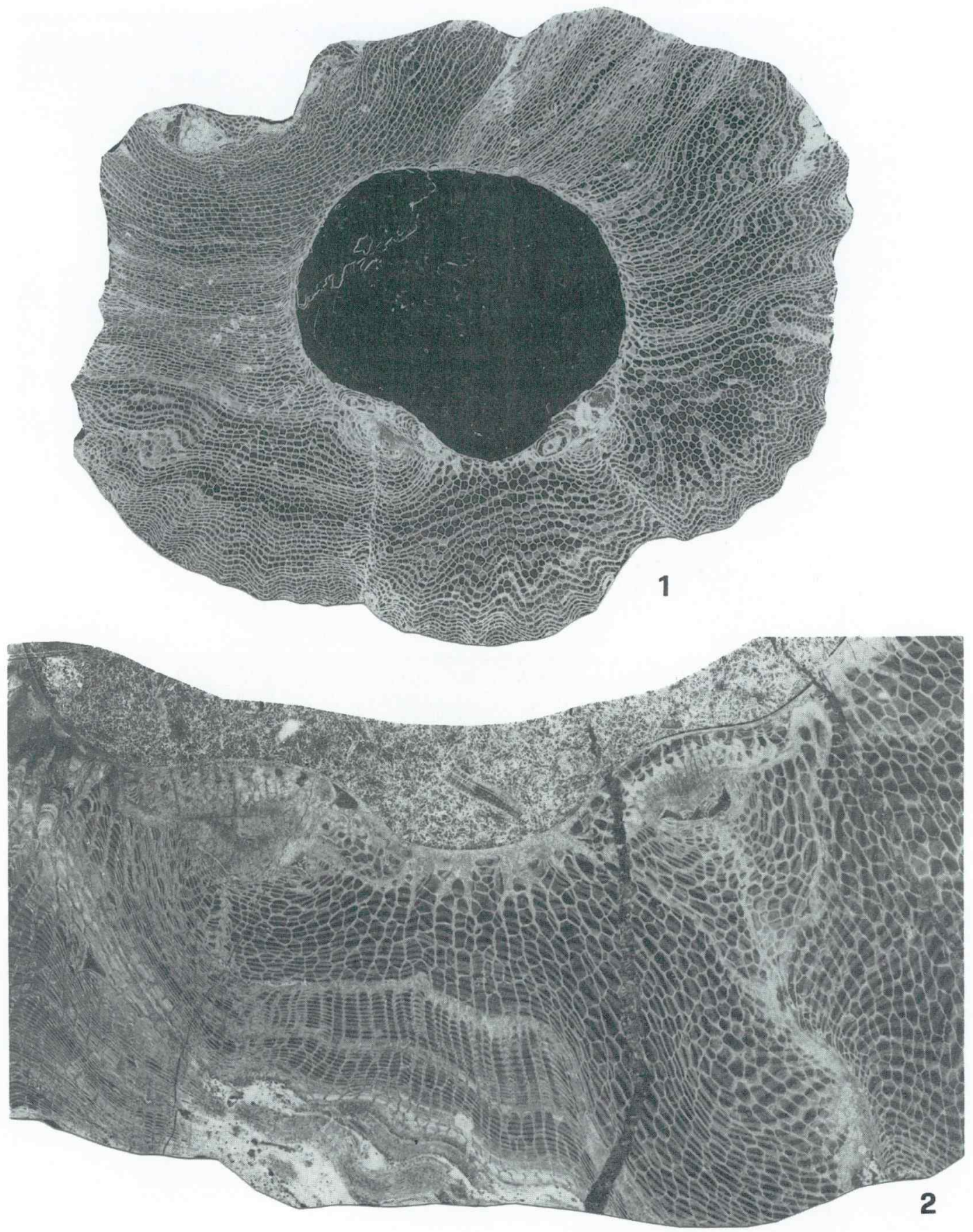

Plate 5

Fig. 1. Lapeirouseia plana. Thin transverse section of right valve. $\times 3.5$.

Fig. 2. Lapeirouseia plana. Detail of the pseudopillars structure. $\times 7.5$. 

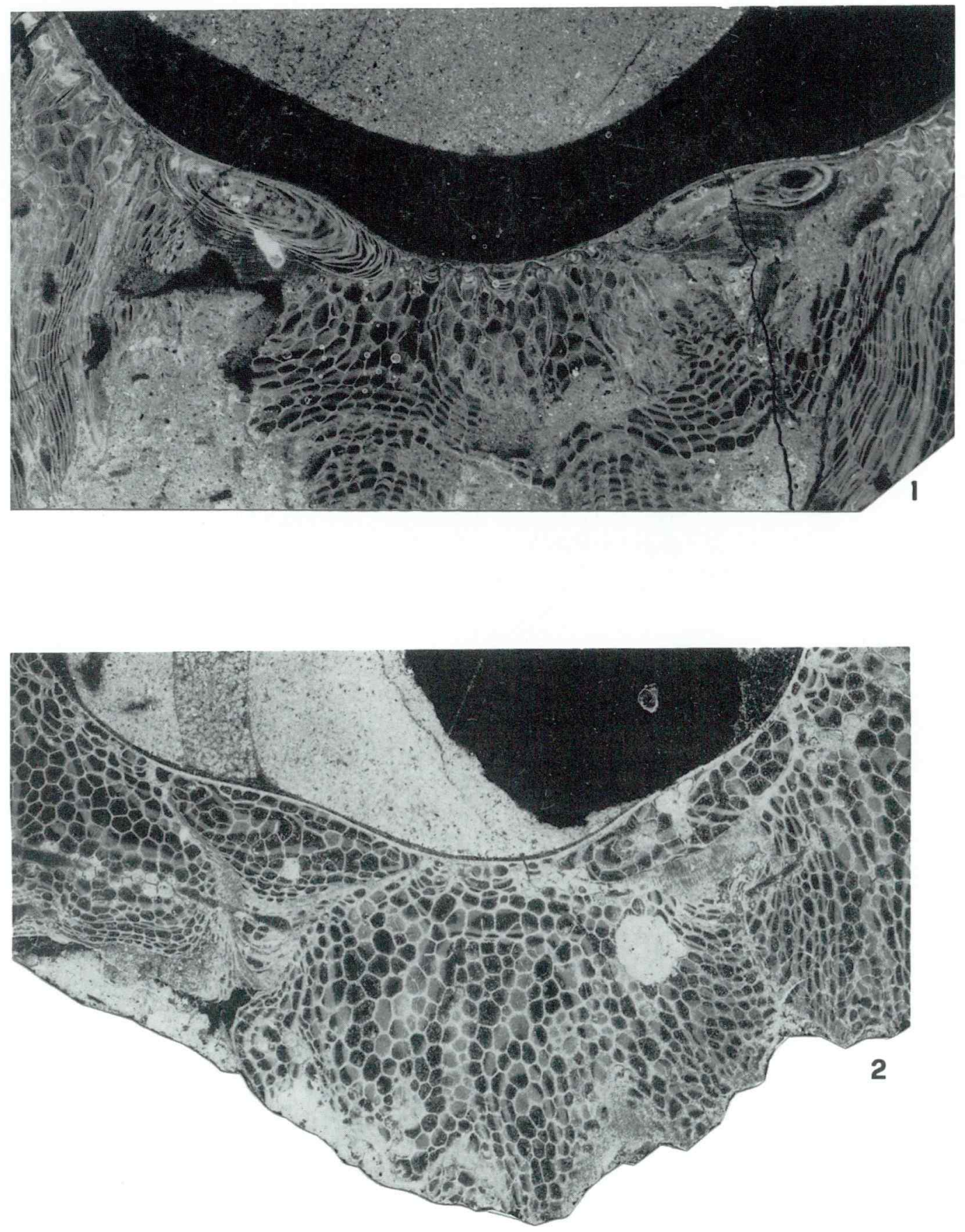

Plate 6

Fig. 1. Lapeirouseia laskarevi. Detail of the pseudopillars structure. $\times 10$.

Fig. 2. Lapeirouseia zitteli. Detail of the pseudopillars structure. $\times 10$. 